\title{
VALUE MEASURING OF TWO GRINDED PAPRIKA VARIETIES
}

\author{
Tóth Horgosi Péter ${ }^{*}$ \\ ${ }^{1}$ Department of Horticulture, Faculty of Horticulture and Rural Development, János Neumann \\ University, Hungary \\ https://doi.org/10.47833/2020.2.AGR.035
}

\section{Keywords: \\ Spice pepper \\ Capsaicin \\ ASTA \\ Dry matter content}

\section{Article history:}

Received

Revised

Accepted
15 May 2020

25 May 2020

\begin{abstract}
In our experiment we measured the following values: dry matter content, capsaicinoid, and pigment content. The two hybrid paprika varieties were: Hetényi Parázs F1, and Hetényi Triász F1. Open field experiments were carried out at Univer Product Plc. in Szentkirály in 2018
\end{abstract}

\section{Introduction}

Ripe fruits of either vegetable or spice red-bell pepper are a good source of nutritionally important phytochemicals including carotenoids, to copherols, vitamin $C$ and poly-phenols $[1,8]$. Adequate daily intake of carotenoids and other antioxidants especially from fruits and vegetables has been recommended to sustain optimal health;moreover, data from epidemiological studies consistently showed correlation between the intake of fruits and vegetables and the incidence of several diseases such as cardiovascular, ophthalmological, gastrointestinal or neurodegenerative disorder and some type of cancer [2,9].

Consumption of products of red pepper has been reported to have interesting biological effects. Cancer chemopreventive activity of carotenoids in the fruits of red paprika Capsicum annuum has been confirmed by [3]. The intense and characteristic red color of Capsicum fruits is principally due to the pigments of capsanthin and capsorubin [4,7]. In most of European pepper producing countries, particularly Hungary, there was a marked decrease in the arable land production of spice red pepper, during the last 10 years, due to high cost of production, low level of financial support and climate change. To overcome such problems cultivation under plastic houses (idoor) has become an alternative solution. Among many advantages of such technology yield, period of cultivation and crop quality are accentuated $[5,6]$.

\section{Method}

In our experiment we measured the following values: dry matter content, capsaicinoid, and pigment content. The two hybrid paprika varieties were: Hetényi Parázs F1, and Hetényi Triász F1. This open field experiments were carried out at Univer Product Plc. in Szentkirály in2018

After the harvest, we dried our samples traditionally for forty days. It was the first stage of the drying method. In the second stage, we dried the fruits for twenty-four hours in $70 \mathrm{C}^{\circ}$ in a special oven (Figure 1 ).

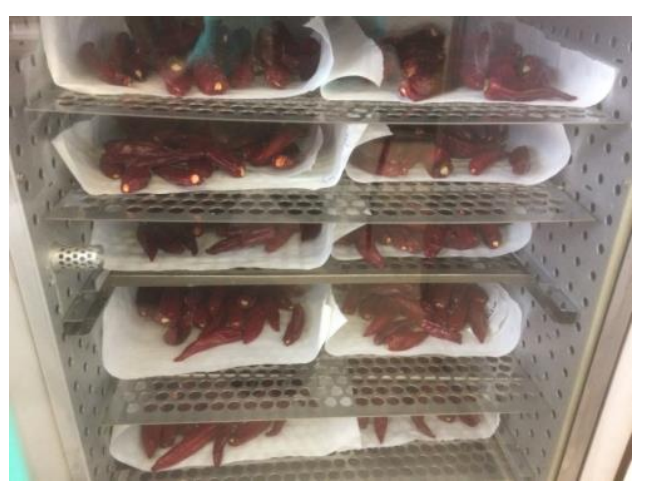

\footnotetext{
*Corresponding author: E-mail address: tohopeti@gmail.com
} 
Figure 1: Drying the samples

In the next movement, we grinded the dried samples. For this step we use a coffee grinder (Figure 2).

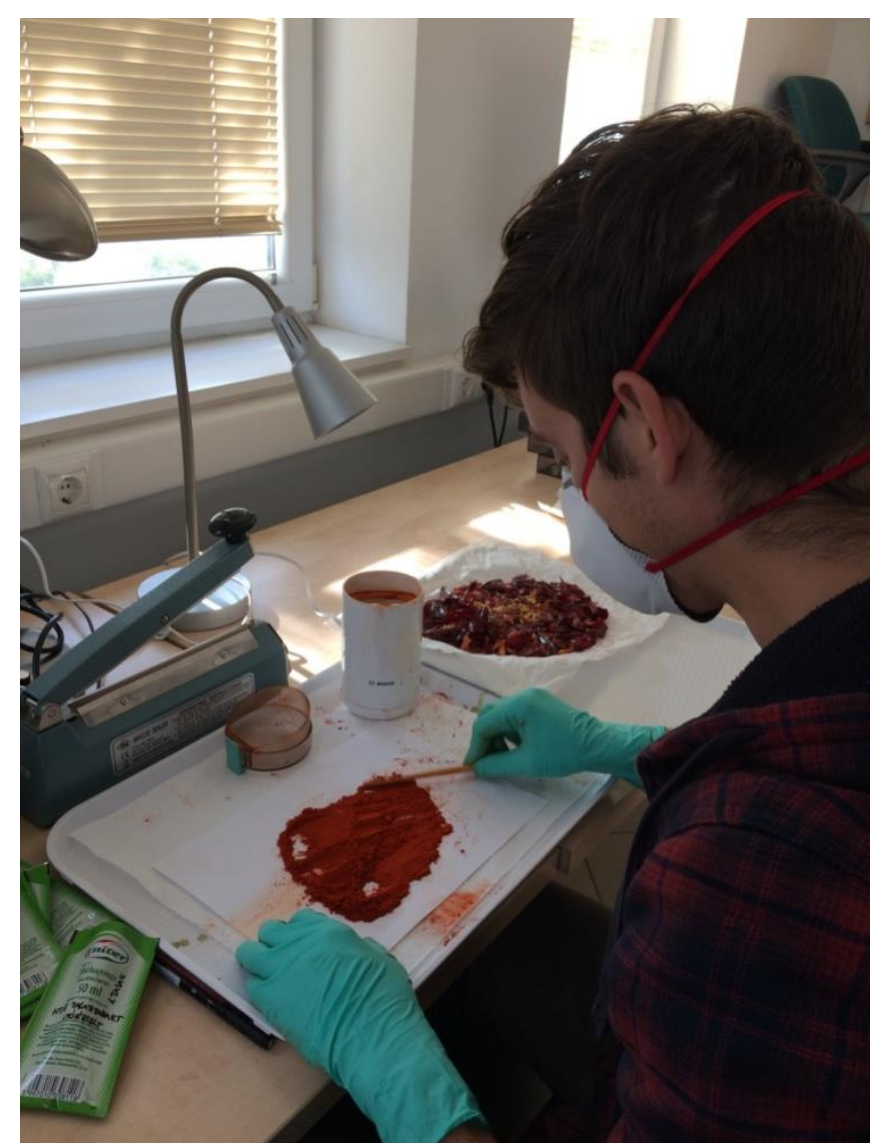

Figure 2: Grinded sample

In the laboratory our coworkers used our samples to make a capsaicinoide, dry matter and pigment content examinations. 


\section{Results}

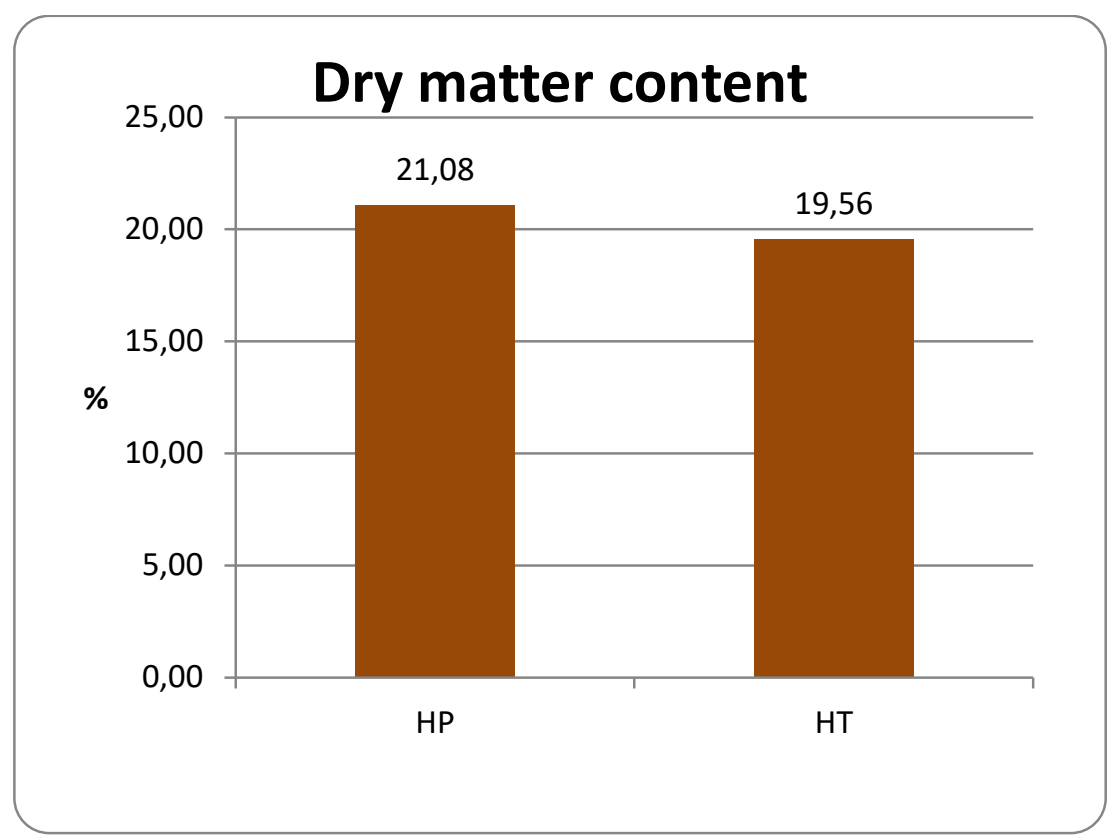

Figure 3: Dry matter content

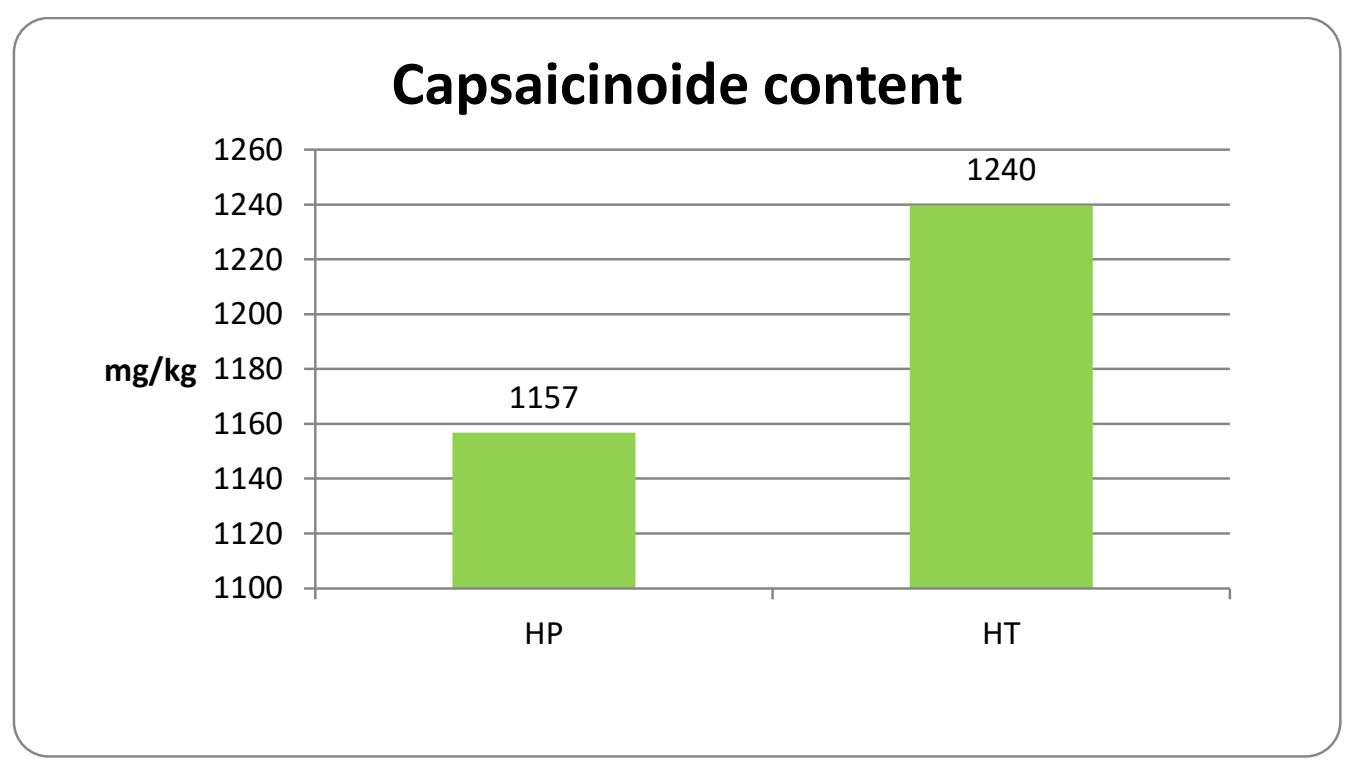

Figure 4. Capsaicinoide content 


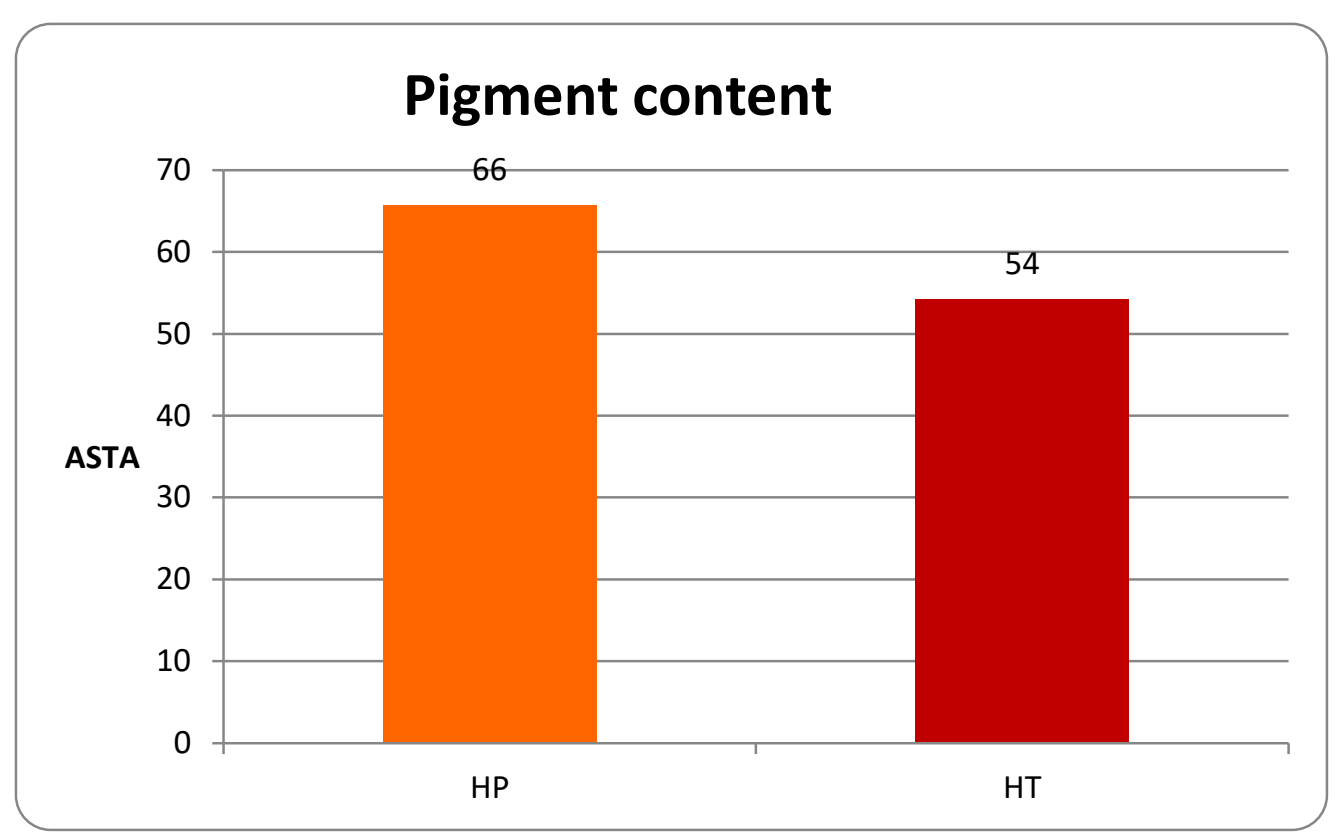

Figure 5: Pigment content

\section{Discussion}

After the measurements, we found minimal differences between the dry matter content (Figure 3). It means that the Hetényi Parázs $(21,08 \%)$, and the Triász $(19,56 \%)$ is also a good industrial raw material.

The capsaicinoide content (Figure 4.) in the Hetényi Triász $(1240 \mathrm{mg} / \mathrm{kg}$ ) was bigger than in the Hetényi Parázs $(1157 \mathrm{mg} / \mathrm{kg}$ ). Although both variety required for the strong category.

For the pigment content (Figure 5.), ASTA values were measured. The Hetényi Triász (54) and the Hetényi Parázs (66) is also belongs to the sweet-noble category.

\section{Acknowledgment}

Thank you for the support of the research carried out in the framework of the EFOP-3.6.2-162017-00012 „Developing a functional, healthy and safe food product chain model from field to table in a thematic research network". The project is funded by the Hungarian State and the European Union, co-financed by the European Social Fund, and is part of the Széchenyi 2020 program.

\section{References}

[1] Daood, H. G., Vinkler,M., Markush, F., Hebshi, E. A., \& Biacs, P. (1996). Antioxidant vitamin content of spice red pepper (paprika) as affected by technological and arietal factors. Food Chemistry, 55, 356-372.

[2] Christen,W. G. (1994). Antioxidants and eye disease. The American Journal of Medicine, 97, 3A-17S.

[3] Maoka, T.,Mochida, K., Kuzoka,M., Ito, Y., Fujiwara, Y., Hashimota, K., et al. (2001). Cancer chemopreventive activity of carotenoids in the fruits of red paprika Capsicumannuum L. Cancer Letters, 172, 103-109.

[4] Ittah, Y., Kanner, J., Granit, R., 1993. Hydrolysis study of carotenoid pigments of paprika (Capsicum annuum L. variety Lehava) by HPLC/ photodiode array detection. Journal of Agricultural and Food Chemistry 41, 899-901.

[5] Somogyi, N. (2010). Breeding and cultivation technology of hybrid spice red pepper. Ph.D. Dissertation. Keszthely, Hungary: Pannon University, Georgikon Faculty. 
[6] Daood, H. G. Palotás, G. Palotás, G. Somogyi, Gy. Pék, Z. Helyes, L. (2014): Carotenoid and antioxidant content of ground paprika from indoor- cultivated traditional varieties and new hybrids of spice red peppers. Food Research International 65, pp. 231-237. http://dx.doi.org/10.1016/j.foodres.2014.04.048

[7] Koncsek, A. Kuppai, L. Helyes, L. Bori, Zs. Daood, H., (2016): Storage stability of carotenoids in paprika from conventional, organic and frost-damaged spice red peppers as influenced by illumination and antioxidant supplementation. Journal of Food Processing and Preservation. 40, pp. 453-462. doi:10.1111/jfpp.12623, ISSN $1745-4549$

[8] Duc, N.H., Mayer, Z., Pék, Z., Helyes, L., Posta, K. (2017): Combined inoculation of arbuscular mycorrhizal fungi, Pseudomonas Fluorescens and Trichoderma spp. For enhancing defense enzymes and yield of three pepper cultivars, APPLIED ECOLOGY AND ENVIRONMENTAL RESEARCH 15. (3): pp. 1825-1829. DOI: 10.15666/aeer/1503_18151829 ISSN: 15891623

[9] Darázsi Ledóné, H., Pék, Z., Helyes, L. and Szuvandzsiev, P. (2017). Influence of colour net shading on quantity and quality of sweet pepper yield. Acta Hortic. 1170, pp. 359-364. DOI: 10.17660/ActaHortic.2017.1170.44 https://doi.org/10.17660/ActaHortic.2017.1170.44 